\title{
The Impact of Crossfit Open 2019 on the Functional State of Amateur Athletes
}

Kozhevnikov V.S.

Department "Physical culture and sports technologies» Izhevsk State Technical University Named after M. T. Kalashnikov»

wattsong@mail.ru

\author{
Gibadullin I.G. \\ Department «Physical culture and sports technologies» \\ Izhevsk State technical University named after M. T. \\ Kalashnikov» \\ ffkis@istu.ru
}

\begin{abstract}
The aim of the study was to study the functional state of amateur athletes engaged in crossfit, before the load and 5 minutes after its completion, on the complex of functional diagnostics "omega-C". Testing was carried out 4 times before and after the performance of the complexes: Crossfit Open 19.2, Crossfit Open 19.3, Crossfit Open 19.4, as well as after the training, planned taking into account the peculiarities of the energy supply involved. The study involved 13 men aged 24-32 years, 1-2 years of experience. According to the results of testing the functional state of amateur athletes, it was found that the lowest increase in heart rate (up to $\mathbf{9 2 . 2}$ beats / min) 5 minutes after the load was revealed after training, planned taking into account the peculiarities of energy supply of the participants. After such training, the lowest stress index was recorded (475.25). ed.). The highest heart rate (103.6 beats / min) and "voltage index" (1049.2).units) are fixed after performing the crossfit Open 19.4 complex. Also after a workout planned with the features of energy involved, revealed the smallest decrease in the level of adaptation to physical loads (to $21.1 \%$ ), the fitness level of the body (to $18.2 \%$ ), the level of energy security (to $29.7 \%$ ), emotional state (to $28.4 \%$ ), the cumulative index sportswear (24.4 per cent). The most significant decrease in these indicators was also recorded after the crossfit Open 19.4 complex.
\end{abstract}

Keywords — crossfit; functional state.

\section{INTRADUCTION}

Strength functional training (crossfit) is a special training system developed by G. Glassman [1]. Its purpose is to achieve a high level of general physical fitness. One of the most important advantages of crossfit is the lack of narrow specialization. This highly effective program combines exercises from different sports areas [4]. An important disadvantage of crossfit is a large proportion of the competitive method in the training of amateur athletes, when almost every training session is tasked to perform a high-intensity set of exercises in a minimum time, in the absence of control over the physiological characteristics of the athlete, and without taking into account his individual characteristics. This often leads to such consequences as increased injuries [3, 7], negative effects on the myocardium during prolonged work at a high pulse [6] and the possibility of rhabdomiliosis [7]. Such consequences arise as a result of the sports training theory and methodology basic principles neglect when planning classes [5].

\section{RESEARCH METHODOLOGY}

The purpose of the study: to compare the impact of crossfit Open 2019 complexes and training, planned taking into account the provisions of the theory and methodology of physical education and individual characteristics of the participants, on their functional state.

The study involved 13 men aged 24-32 years, 1-2 years of experience.

Before the training and 5 minutes after its completion the subjects were tested on the complex of functional diagnostics "omega-C". This is a specialized software and hardware complex designed for an objective assessment of the physical condition of athletes.

The following indicators were evaluated: heart rate, stress index, level of adaptation to physical activity, level of the organism fitness, level of energy supply, psychoemotional state, integral indicator of sports form.

The study was conducted 1 time per week for 4 weeks.

The following complexes were performed:

Week 1-Crossfit Open 19.2.

Week 2-Crossfit Open 19.3

Week 3-Crossfit Open 19.4

Week 4-Training planned taking into account the peculiarities energy of students supply (table 1).

All subjects were divided into 3 groups "aerobic type", "mixed type" and "anaerobic type" after preliminary testing using the method of "rapid diagnosis of functional state and reserve capabilities of the organism D\&K Test" [2].

\section{RESULTS}

To plan the training, the athletes were divided into 2 groups "aerobic type" and "anaerobic type". Athletes of the "mixed type" were assigned to one of these groups 
according to their preferences. Table 1 shows the structure of the training.

TABLE 1- PLANNED TRAINING TAKING INTO ACCOUNT FEATURES OF POWER SUPPLY OF THE ENGAGED

\begin{tabular}{|c|c|c|c|}
\hline $\begin{array}{l}\text { Part of the } \\
\text { workout }\end{array}$ & Content & $\begin{array}{c}\text { Dosage for "aerobic } \\
\text { type" }\end{array}$ & $\begin{array}{c}\text { Dosage for } \\
\text { "anaerobic } \\
\text { type" }\end{array}$ \\
\hline \multirow{5}{*}{ Workout } & $\begin{array}{c}\text { Self- } \\
\text { warming }\end{array}$ & \multicolumn{2}{|l|}{15 Min } \\
\hline & & 2 rounds with each hand & $\begin{array}{c}4 \text { rounds with } \\
\text { each hand }\end{array}$ \\
\hline & $\begin{array}{c}\text { The } \\
\text { weighty } \\
\text { jerk }\end{array}$ & 16 Times & 8 Times \\
\hline & Mill & 16 Times & 8 Times \\
\hline & $\begin{array}{l}\text { Squats } \\
\text { with } \\
\text { weights in } \\
1 \text { hand }\end{array}$ & 16 Times & 8 Times \\
\hline $\begin{array}{c}\text { The main part } \\
\text { (improving the } \\
\text { technique) }\end{array}$ & $\begin{array}{l}\text { Exits on } \\
\text { the } \\
\text { crossbar }\end{array}$ & \multicolumn{2}{|c|}{5 episodes 2 times, run every 2 minutes } \\
\hline $\begin{array}{l}\text { The main part } \\
\text { (force } \\
\text { development) }\end{array}$ & $\begin{array}{c}\text { Squats } \\
\text { with a } \\
\text { barbell on } \\
\text { the } \\
\text { shoulders }\end{array}$ & $\begin{array}{c}5 \text { series } 4 \text { times weight } \\
80 \% \text { of } 1 \mathrm{PM} \text {, rest } 3 \\
\text { minutes }\end{array}$ & $\begin{array}{l}5 \text { episodes } 2 \\
\text { times weight } \\
90 \% \text { of } 1 \mathrm{PM} \text {, } \\
\text { rest } 3 \text { minutes }\end{array}$ \\
\hline \multirow{4}{*}{$\begin{array}{l}\text { The main part } \\
\text { (development } \\
\text { of special } \\
\text { endurance) }\end{array}$} & & $\begin{array}{l}\text { Runs every } 2 \text { minutes } \\
\text { for } 18 \text { minutes }\end{array}$ & $\begin{array}{c}\text { Runs every } \\
\text { minute for } 18 \\
\text { minutes }\end{array}$ \\
\hline & $\begin{array}{l}\text { Taking a } \\
\text { barbell } \\
\text { from a } \\
\text { hanging }\end{array}$ & $\begin{array}{l}12 \text { times (weight } 60 \% \\
\text { from } 1 \mathrm{PM} \text { ) }\end{array}$ & $\begin{array}{c}6 \text { times } \\
\text { (weight } 60 \% \\
\text { from } 1 \mathrm{PM} \text { ) }\end{array}$ \\
\hline & $\begin{array}{l}\text { Lunges } \\
\text { with } \\
\text { pancake }\end{array}$ & 20 Times & 10 Times \\
\hline & $\begin{array}{l}\text { Прыжки } \\
\text { в длину }\end{array}$ & 16 Times & 8 Times \\
\hline The final part & Running & \multicolumn{2}{|l|}{$2000 \mathrm{M}$} \\
\hline $\begin{array}{l}\text { after testing at } \\
\text { the Omega-C } \\
\text { complex) }\end{array}$ & $\begin{array}{l}\text { Flexibility } \\
\text { exercises }\end{array}$ & \multicolumn{2}{|l|}{$10 \mathrm{Min}$} \\
\hline
\end{tabular}

\section{DISCUSSION}

According to the results of testing the functional state of amateur athletes, it was found that the lowest increase in heart rate (up to 92.2 beats / $\min$ ) 5 minutes after the load was revealed after training, planned taking into account the peculiarities of energy supply.

After such training, the lowest stress index was recorded (475.25). units). The highest heart rate (103.6 beats / min) and "voltage Index" (1049.2).units) are fixed after performing the crossfit Open 19.4 complex

Also, after the training, planned with the characteristics of the participants energy supply, the lowest reduction (figure 3-7) level of adaptation to physical activity (up to $21.1 \%$ ), the level of training of the body (up to $18.2 \%$ ), the level of adaptation to physical activity (up to $18.2 \%$ ), the level of physical activity (up to $18.2 \%$ ), the level of energy security (up to $29.7 \%$ ), psycho-emotional state (up to $28.4 \%)$, integral indicator of sports form $(24.4 \%)$.

\section{V.CONCLUSION}

A characteristic feature of Crossfit trainings is their multidirectional and high intensity, which makes them a highly effective means of training athletes. However, too much of the competitive method often leads to adverse effects on the body involved, the emergence of overtraining state and increased injuries. The performance of Crossfit complexes of various directions lead to a decrease in the functional state of the participants after training by 40-60\% and to a significant increase in the voltage of the regulatory systems of the body after training (over 1000). the greatest decrease in the functional capabilities of the body, the greatest increase in heart rate and stress index of the regulatory systems of the body, recorded after the complex "Open 19.4". As a result of high-intensity training with regulated intervals of rest and load planned taking into account the type of energy supply of the muscular system, a smaller decrease in indicators characterizing the functional state of the body was recorded. Lower values of heart rate after exercise and lower stress in the regulatory systems of the body are recorded.

Planning training in Crossfit should be carried out taking into account the type of energy supply of the muscular system involved and in strict accordance with the basic provisions of the theory and methodology of sports training. Strictly regulate the intervals of rest. Significantly reduce the share of the competitive method. To carry out operational control over the state of the patient with the help of heart rate monitors.

\section{References}

[1] Greg Glassman. Guidelines for CrossFit workouts. 2008, 124

[2] Gibadullin I. G., Kozhevnikov V.S. Features of planning of training process at football players of 15-16 years on the basis of the account of their bioenergetic types. Izhevsk: publishing house of ISTU. 2011, 152.

[3] Dorontsev A.V., Medvedeva A.S. Pedagogical and medical control of the vertebral region during crossfit classes. Modern scientist. 2017, vol. 4., pp. 156-159.

[4] Alexsandr S. Kuznetsov. Russian Professor's meeting. Russian Journal of Physical Education and Sport. 2019, 14(1), pp. 17-22. DOI: 10.14526/2070-4798-2019-14-1-18-24

[5] Mushenko V. A., Soloviev V.Yu. Theoretical aspects of competitions in functional all-around. Modern aspects of healthy lifestyle: Materials of the VI regional scientific and practical conference. 2017, pp. 143-144

[6] Savatenkov V. A. high-Intensity functional training in the training process of athletes. European Research. 2016, vol. 2, pp. 107-109.

[7] Seluyanov V. N. Heart is not a machine [Electronic resource]. URL: http://bike4u.ru/ uploading/serdtze.pdf. (Date of application: 05.09.2019).)

[8] Timokhina N. V. Kalugina Y.S. Crossfit training in physical education classes with students of 3-4 courses, harm or benefit. Nauka. 2020, 2017, vol. 3, pp. 126-129. 